\title{
Land use/Land Cover Changes and Causes of Deforestation in the Wilberforce Island, Bayelsa State, Nigeria
}

\author{
${ }^{* 1}$ BARIWENI, P A.; ${ }^{2}$ ANDREW, C E
}

\author{
Department of Geography \& Environmental Management \\ Niger Delta University, Wilberforce Island, Bayelsa State \\ *Corresponding Author e-mail: 1.pbariweni@yahoo.com 2.andrewcomforte@gmail.com
}

\begin{abstract}
The objective of this paper is to provide the non-existent data on land use/land cover changes in the Wilberforce Island for the purposes of determining the causes of deforestation and changes in the vegetation cover for a 13 - year period. Accordingly, 125 questionnaires were administered in five communities to determine the causes of deforestation. Satellite imageries for 2002 and 2015 were also acquired from Landsat 7 and 8 respectively and analysed with the Quantum Geography Information System (QGIS) software to obtain the various land use/land cover changes. The semi - Automatic Classification Plugin Version 4.9.1 of the QGIS was used for the land use/land cover classification with a supervised classification method. Each satellite imagery was classified into 8 categories using their reflectance values and the error matrix was used to show the level of accuracy of the classified imageries. Results from the study indicated that the major drivers of deforestation were logging, farming, building of houses and fuel wood fetching. Results from satellite imageries also showed that forest and sparse vegetation/grassland decreased from $73.34 \%$ and $10.32 \%$ to $51.34 \%$ and $8.08 \%$ between 2002 and 2015 respectively, while farmland and residential area increased from $10.71 \%$ and $0.44 \%$ to 30.575 and $1.72 \%$ for the same period respectively. It was concluded that land use/cover changes was due to deforestation to provide raw materials for wood industries, and space for agriculture and building of house for the increasing population in the area. The implications of deforestation for biodiversity and climate change have been highlighted. (C) JASEM

https://dx.doi.org/10.4314/jasem.v21i6.11
\end{abstract}

Keywords: Deforestation, land use/land cover changes, Wilberforce Island

Land use involves the management and modification of natural environment or wilderness into built environment such as settlements and semi-natural habitats such as arable fields, pastures, and managed woods, while Land cover is the physical material at the surface of the earth and includes grass, asphalt, trees, bare ground, water, etc (Wikipedia, 2017). Deforestation is a global environmental hazard leading to land use and land cover changes. According to the United Nation Food and Agriculture Organization (FAO) (2010), the global forests declined by about 5.2 million hectares every year between the year 2000 and 2010. Nigeria has one of the highest rates of deforestation in the world, having continuously lost about 410,100 hectare per year between 2005 and 2010 at a rate of $3.12 \%$ per annum (Ozor \& Odo, 2008). The main drivers of deforestation in the country have been agriculture, logging, grazing, urbanisation, road construction and mining (FAO, 2010; Ozor \& Odo, 2008). Nigeria could face the possibility of timber and fuelwood scarcity towards the end of the century (Aliyu, Modibbo, Madugu \& Ayo, 2014).

Deforestation has many negative effects on the environment. The most dramatic impact is loss of habitat for millions of species with serious implication for eco - tourism and loss of biodiversity. Deforestation also drives climate change (National Geographic, 2015), and is considered to be one of the contributing factors to global climate change (Bradford, 2015).

While there are records of the causes and levels of deforestation in many parts of Nigeria, there are no records of how much forest cover have been lost to human activities or what the major cause(s) of deforestation in the Wilberforce Island are. The objectives of this study is therefore to provide the non-existent data on land use land cover changes in the Wilberforce Island for the purposes of determining the causes of deforestation and changes in the vegetation cover for a 13 - year period.

\section{MATERIALS AND METHODS}

The study area: The Wilberforce Island is located between latitude $4^{\circ} 51^{\prime} \mathrm{N}$ to $5^{\circ} 02^{\prime} \mathrm{N}$, and longitude $6^{\circ}$ $04^{\prime} \mathrm{E}$ to $6^{\circ} 17^{\prime} \mathrm{E}$. The area cuts across KolokumaOpokuma, Yenagoa, Southern Ijaw and Sagbama Local Government Areas in Bayelsa State and is drained mainly by the Nun River which is a distributary of the River Niger. Vegetation is the tropical rainforest which encourages lumbering. The Island hosts the Niger Delta University, whose establishment in 2000 has encouraged massive population influx into the Island leading to a rapid change in land use and land cover.

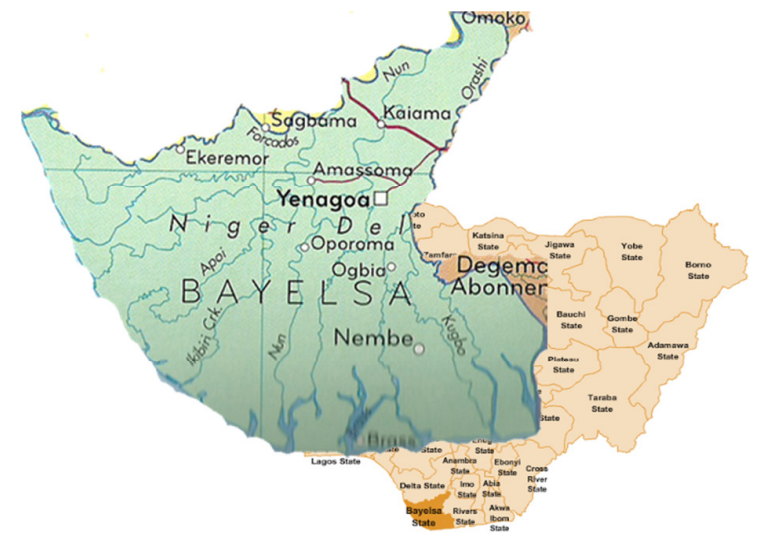




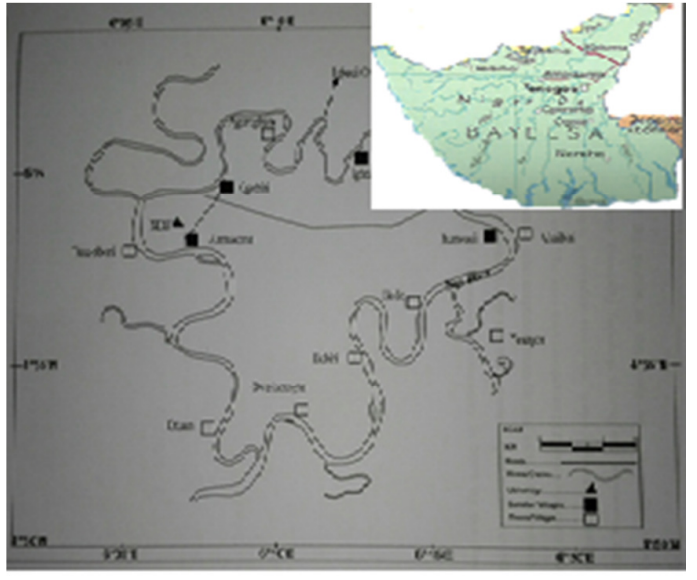

Fig 1: The Wilberforce Island

Primary and secondary data were used for this study. Primary data was obtained through the administration of self - administered questionnaires. One Hundred and Twenty-Five (125) questionnaires were administered in five communities (Amassoma, Ogobiri, Agudama/Ekpetiama, Igbedi and Bumoudi) selected from the Wilberforce Island using the purposeful sampling technique for this study. The questionnaires were designed to obtain information regarding the level of awareness of deforestation activity and its major causes in the study area. The primary data obtained were analyzed with the Measures of Central Tendency and Proportions, as well as ranks.

The secondary data for this study were the satellite imageries of 2002 and 2015, which were acquired from Landsat 7 and Landsat 8 respectively. These images were analysed with the Quantum Geographic Information System (QGIS) Software to obtain the various land use/land cover of the study area. Characteristics of these acquired satellite imageries are shown in Table 1. The Semi-Automatic Classification Plugin Version 4.9.1 of the QGIS software was used for the land use/land cover classification with a supervised classification method. Each satellite imagery was classified into 8 categories (Table 2) using their reflectance values and the error matrix was used to show the level of accuracy of the classified imageries (Table $5 \&$ 6). The level of deforestation was assessed with the PostClassification Comparison Method to detect changes in the classified images of 2002 and 2015.

Table 1: Characteristics of the Acquired Satellite Imageries

\begin{tabular}{llllllllll}
\hline S/N & $\begin{array}{l}\text { Spacecraft } \\
\text { ID }\end{array}$ & $\begin{array}{l}\text { Sensor } \\
\text { ID }\end{array}$ & Resolution & $\begin{array}{l}\text { Date of } \\
\text { Acquisition }\end{array}$ & Source & $\begin{array}{l}\text { Elevation } \\
\text { Source }\end{array}$ & $\begin{array}{l}\text { Station } \\
\text { ID }\end{array}$ & $\begin{array}{l}\text { Data } \\
\text { Type }\end{array}$ & $\begin{array}{l}\text { Output } \\
\text { Format }\end{array}$ \\
\hline $\mathbf{1}$ & Landsat 7 & ETM & $30 \times 30$ & $30 / 12 / 2002$ & $\begin{array}{l}\text { U.S. Geological } \\
\text { Survey }\end{array}$ & GLS2000 & EDC & LIT & GEOTIFF \\
$\mathbf{2}$ & Landsat 8 & $\begin{array}{l}\text { OLI } \\
\text { TIRS }\end{array}$ & $30 \times 30$ & $26 / 12 / 2015$ & $\begin{array}{l}\text { U.S. Geological } \\
\text { Survey }\end{array}$ & GLS2000 & LGN & LIT & GEOTIFF \\
\hline
\end{tabular}

\begin{tabular}{lll}
\hline & \multicolumn{2}{c}{ Table 2: Land use - Land cover Classification Scheme and their General Descriptions } \\
\hline Codes & LULC Categories & General Description \\
\hline $\mathbf{1 1}$ & Sand Fill & An area of land that is covered with sand. \\
$\mathbf{1 2}$ & Beach & An area of land with bare soil or sand deposit, including river banks. \\
$\mathbf{2 1}$ & Farmland & An area of land devoted to agriculture. \\
$\mathbf{2 2}$ & Forest & Trees and other plants in a large densely wooded area. \\
$\mathbf{2 3}$ & Sparse Vegetation/Grassland & An area of land covered with different types of trees and other plants in a \\
& & sparsely manner. \\
$\mathbf{3 1}$ & Pond & An area that is comprised with a small lake \\
$\mathbf{3 2}$ & River/Creek & A natural stream of water. \\
$\mathbf{4 1}$ & Residential Area & An area occupied by housing including road network and other facilities. \\
\hline
\end{tabular}

\section{RESULTS AND DISCUSSION}

Result from the study showed that $97.6 \%$ of the respondents were aware of deforestation activities going on in the Wilberforce Island. With respect to the causes of deforestation in the Wilberforce Island, results indicated that logging and farming were the most significant (Table 3). Most respondents in the study ranked logging as the major cause of deforestation in the study area, followed by farming. The results obtained from the study were found to be similar to those of Akinyemi (2013) and FAO (2010), which confirmed rapid population growth, agricultural expansion, use of fuelwood and logging as the major drivers of deforestation in the Southern part of Nigeria.

Table 3: Causes of Deforestation in the Study Area as Ranked by Respondents

\begin{tabular}{lll}
\hline Causes of Deforestation & Average Score & Rank \\
\hline Logging & 4.89 & 1 \\
Farming & 2.99 & 2 \\
Building of Houses & 1.58 & 3 \\
Firewood Fetching & 1.58 & 3 \\
Road Construction & 1.57 & 4 \\
Siting of Large Projects & 1.21 & 5 \\
\hline
\end{tabular}

The level of deforestation in the study area was detected after applying a Post-Classification Comparison Method (Table 7) to the Land use/Land 
cover analysis results obtained from the classified satellite imageries used for the study. The classified imageries of 2002 and 2015 are shown in Figure 2 and 3.

The result presented in Table 4 shows the area of each Land use/Land cover category for 2002 and 2015. In 2002, Forest and sparse vegetation occupied $73.34 \%$ and $10.32 \%$ of the total land area respectively. This implied that the total Vegetation

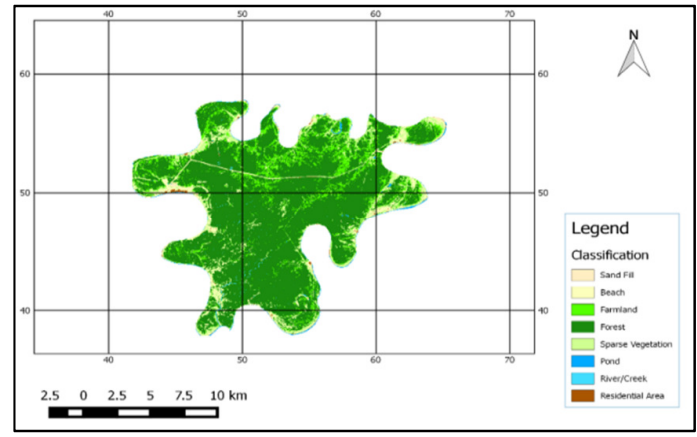

Fig 2: The Land use/Land cover of Wilberforce (2015) Island (2002) (Source: Author's fieldwork, 2016)

Farmland now occupied $30.57 \%$ of the total land area, showing an increase of $185.35 \%$ of its original cover; and Residential Area occupied $1.72 \%$ of the total land mass, showing an increase of $290.83 \%$ of its original cover. This implied that the vegetation cover was $83.80 \%$ of the total land area. On the other hand residential area occupied $0.44 \%$ of the total land area while farmland occupied $10.71 \%$ of the total land area. By 2015, Forest cover accounted for only $51.34 \%$ of the total land area, showing a decrease of $30.02 \%$ of its original cover. Also, Sparse Vegetation occupied $8.08 \%$ of the total land area, showing a reduction of $21.75 \%$ of its original cover (Figure $2 \&$ $3)$.

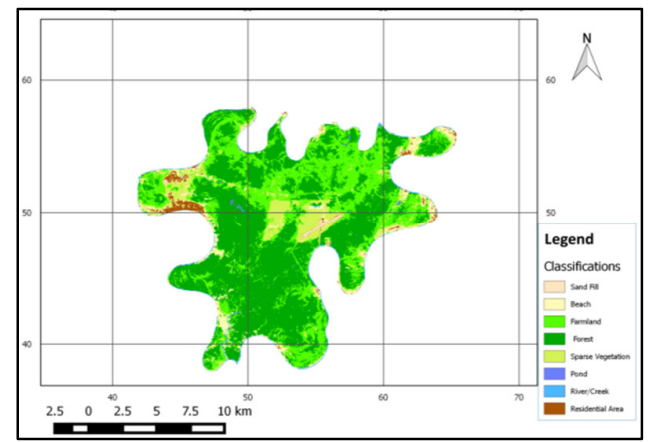

Fig 3: The Land use/Land cover of Wilberforce Island

cover in the study area decreased considerably within the 13 years' time-frame principally as a result of the increase in the residential areas and farmlands (Table 7).

Table 4: The Land use/Land cover of Wilberforce Island 2002 and 2015

\begin{tabular}{|c|c|c|c|c|c|c|}
\hline \multirow[t]{2}{*}{ LULC Categories } & \multicolumn{3}{|l|}{2002} & \multicolumn{3}{|l|}{2015} \\
\hline & Area $\left(\mathrm{m}^{2}\right)$ & Area (ha) & $(\%)$ & Area $\left(\mathrm{m}^{2}\right)$ & Area (ha) & $(\%)$ \\
\hline Sand Fill & 356400 & 35.64 & 0.15 & 890100 & 89.01 & 0.38 \\
\hline Beach & 8299800 & 829.98 & 3.58 & 13896900 & 1389.69 & 5.98 \\
\hline Farmland & 24837300 & 2483.73 & 10.71 & 70902900 & 7090.29 & 30.57 \\
\hline Forest & 170154900 & 17015.49 & 73.34 & 119082600 & 11908.26 & 51.34 \\
\hline Sparse Vegetation/Grassland & 23949900 & 2394.99 & 10.32 & 18741600 & 1874.16 & 8.08 \\
\hline Pond & 1066500 & 106.65 & 0.46 & 597600 & 59.76 & 0.26 \\
\hline River/Creek & 2307600 & 230.76 & 1.00 & 3870000 & 387 & 1.67 \\
\hline Residential Area & 1020600 & 102.06 & 0.44 & 3988800 & 398.88 & 1.72 \\
\hline Total & 231636600 & 23163.66 & & 231970500 & 23197.05 & \\
\hline
\end{tabular}

Table 5: Error Matrix of the Classified Imagery of 2002

\begin{tabular}{|c|c|c|c|c|c|c|c|c|c|c|}
\hline \multirow[t]{2}{*}{ Classified Image } & \multicolumn{8}{|c|}{ Reference Data } & \multirow{2}{*}{$\begin{array}{l}\text { Row } \\
\text { Total }\end{array}$} & \multirow{2}{*}{$\begin{array}{l}\text { User's } \\
\text { Accuracy }(\%)\end{array}$} \\
\hline & $(\mathrm{SF})$ & (B) & $(\mathrm{FL})$ & (F) & $(\mathrm{SP} / \mathrm{G})$ & (P) & $(\mathrm{R} / \mathrm{C})$ & (RA) & & \\
\hline Sand Fill (SF) & 59 & 0 & 0 & 0 & 0 & 0 & 0 & 0 & 59 & 100.00 \\
\hline Beach (B) & 0 & 78 & 5 & 0 & 149 & 0 & 0 & 5 & 237 & 32.91 \\
\hline Farm land (FL) & 0 & 0 & 2371 & 1046 & 761 & & 0 & 0 & 4178 & 56.75 \\
\hline Forest $(\mathrm{F})$ & 0 & 0 & 895 & 7209 & 920 & 0 & 10 & 0 & 9034 & 79.80 \\
\hline Sparse Vegetation /Grassland & 0 & 0 & 1125 & 270 & 1118 & 0 & 0 & 0 & 2513 & 44.49 \\
\hline Pond $(\mathrm{P})$ & 0 & 0 & 0 & 0 & 0 & 44 & 7 & 0 & 51 & 86.27 \\
\hline River/Creek (R/C) & 0 & 0 & 0 & 0 & 0 & 12 & 87 & 1 & 100 & 87.00 \\
\hline Residential Area (RA) & 0 & 5 & 0 & 0 & 0 & 0 & 0 & 158 & 163 & 96.93 \\
\hline Total Column & 59 & 83 & 4396 & 8525 & 2948 & 56 & 104 & 164 & 16335 & \\
\hline Procedure's Accuracy (\%) & 100 & 93.98 & 53.94 & 84.56 & 37.92 & 78.57 & 83.65 & 96.34 & & \\
\hline
\end{tabular}

Overall Accuracy $=68.10 \% ;$ Kappa hat classification $=0.48$ 
Table 6: Error Matrix of the Classified Imagery of 2015

\begin{tabular}{|c|c|c|c|c|c|c|c|c|c|c|}
\hline \multirow[t]{2}{*}{ Classified Image } & \multicolumn{8}{|c|}{ Reference Data } & \multirow{2}{*}{$\begin{array}{l}\text { Row } \\
\text { Total }\end{array}$} & \multirow{2}{*}{$\begin{array}{l}\text { User's } \\
\text { Accuracy } \\
(\%)\end{array}$} \\
\hline & (SF) & (B) & (FL) & (F) & (SP/G) & (P) & $(\mathrm{R} / \mathrm{C})$ & (RA) & & \\
\hline Sand Fill (SF) & 35 & 0 & 0 & 0 & 0 & 0 & 0 & 0 & 35 & 100.0 \\
\hline Beach (B) & 0 & 494 & 0 & 0 & 0 & 0 & 0 & 1 & 495 & 99.80 \\
\hline Farm land (FL) & 0 & 0 & 1497 & 21 & 0 & & 0 & 0 & 1518 & 98.62 \\
\hline Forest $(\mathrm{F})$ & 0 & 0 & 18 & 6408 & 0 & 1 & 8 & 0 & 6435 & 99.58 \\
\hline $\begin{array}{l}\text { Sparse Vegetation } \\
\text { /Grassland }(\mathrm{SP} / \mathrm{G})\end{array}$ & 0 & 0 & 0 & 0 & 838 & 0 & 0 & 0 & 838 & 100 \\
\hline Pond (P) & 0 & 0 & 0 & 0 & 0 & 52 & 0 & 0 & 52 & 100.0 \\
\hline River/Creek (R/C) & 0 & 0 & 0 & 0 & 0 & 2 & 128 & 0 & 130 & 98.46 \\
\hline $\begin{array}{l}\text { Residential Area } \\
\text { (RA) }\end{array}$ & 0 & 0 & 0 & 0 & 0 & 0 & 0 & 519 & 519 & 100.0 \\
\hline Total Column & 35 & 494 & 1515 & 6429 & 838 & 55 & 136 & 520 & 10022 & \\
\hline $\begin{array}{l}\text { Procedure's Accuracy } \\
(\%)\end{array}$ & 100 & 100 & 98.81 & 99.67 & 100 & 94.55 & 94.12 & $\begin{array}{l}99.8 \\
1\end{array}$ & & \\
\hline
\end{tabular}

Table 7: The Land use/Land cover Changes in the Wilberforce Island (2002 - 2015)

\begin{tabular}{lllllll}
\hline LULC Categories & 2002 & & 2015 & & $\begin{array}{l}\text { Change } \\
\text { in }\end{array}$ & $\begin{array}{l}\text { Change } \\
\text { Area in } \%\end{array}$ \\
\cline { 2 - 5 } Sand Fill & Area (ha) & $(\%)$ & Area (ha) & $(\%)$ & & \\
Beach & 35.64 & 0.15 & 89.01 & 0.38 & 53.37 & 149.75 \\
Farmland & 829.98 & 3.58 & 1389.69 & 5.98 & 559.71 & 67.44 \\
Forest & 2483.73 & 10.71 & 7090.29 & 30.57 & 4605.56 & 185.35 \\
Sparse Vegetation/Grassland & 17015.49 & 73.34 & 11908.26 & 51.34 & -5107.23 & -30.02 \\
& 2394.99 & 10.32 & 1874.16 & 8.08 & & -21.75 \\
Pond & & & & & -520.83 & -43.97 \\
River/Creek & 106.65 & 0.46 & 59.76 & 0.26 & -46.89 & 67.71 \\
Residential Area & 230.76 & 1.00 & 387 & 1.67 & 156.24 & 290.83 \\
Total & 102.06 & 0.44 & 398.88 & 1.72 & 296.82 & \\
\hline
\end{tabular}

(-) indicates decrease.

Conclusion: It can be concluded from the study that logging, farming, building of houses and fuel wood fetching are the major causes of deforestation and the observed land use and land cover changes in the Wilberforce Island. The massive reduction in the forest cover, and the associated land use and land cover changes in the study area were due to rapid increase in population following the establishment of the Niger Delta University, and the consequent need for raw materials for wood industries, and space for agriculture to support the burgeoning population as well as for building of houses. This however calls for urgent action to control the high rate of deforestation in the light of current global issues such as global warming and climate change amongst others that requires the protection of the forest.

\section{REFERENCES}

Akinyemi, F.O. (2013). An Assessment of Land-use Change in Cocoa Belt of South-west Nigeria. Internal Journal of Remote Sensing, 34(8), 28582875.

Bradford, A. (2015). Deforestation: Facts, causes and Effects. Live Science Contributor. Live Science. Viewed at http://m.livescience.com/27692deforestation.html 4/09/2015 06:51am.
Aliyu, A., Madibbo, M.A., Medugu, N.I., \& Ayo, O. (2014). Impacts of Deforestation on Socio Economic Devlopment of AkwangaNasarawa State. International journal of Science, Environment and Technology vol.3, No.2, 403-416

FAO. (2010). Global Forest Resources Assessment 2010. Main report FAO Forestry Paper 163. http://www.fao.org/docrep/013/i1757e/i1757e.pdf

National Geographic. (2015). retrieved on 08/10/2015 22:32 environment.nationalgeographic.com/ environment/global-warming/deforestationoverview/

Ozor, N., \& Odo, P. (2008). Agro-Science. Community strategies for the conservation and preservation of forest resources in Nsukka agricultural zone of Nigeria. Journal of Tropical Agriculture, Food, Environment and Extension. Vol. 7, no. 1, p.27-32. ISSN 1119-7455, January 2008, $<$ http://www.agrosciencejournal.com/>.

Wikipedia (2017): Land use/Land cover. Retrieved on 24/8/17 from https://en.wikipedia.org/wiki/land use 